\title{
The Barbarous Moor in Peele's Alcazar (1594)
}

\author{
Fahd Mohammed Taleb Al-Olaqi ${ }^{1, *}$ \\ ${ }^{1}$ Department of English \& Translation, University of Jeddah, Saudi Arabia, Saudi Arabia \\ *Correspondence: University of Jeddah, Jeddah. Faculty of Science \& Arts - Khulais, P.O. B. 355, Khulais 21921, \\ Kingdom of Saudi Arabia. E-mail: falolaqi@uj.edu.sa
}

Received: April 10, 2016

Accepted: June 22, 2016 Online Published: June 24, 2016

doi:10.5430/wjel.v6n2p24

URL: http://dx.doi.org/10.5430/wjel.v6n2p24

\begin{abstract}
The article investigates the sixteenth century Elizabethan view of race and its influence on person's innate character within the context of The Battle of Alcazar. The interest of Elizabethan audience in Moorish matter is remarkable in drama. The Elizabethans consider the Africa as the domain of war, conquest, fratricide, lust and treachery. The Moors are often portrayed as violent villains that violate human morality. George Peele has overturned the racist stereotypes of his days in presenting Muly Mahamet, as Machiavellian politician, in the play. Peele's characterization of this Moorish Other embodies negative traits shared by the society at large, such as violence evilness, and treachery. Certainly, Muly Mahamet's depiction is the patchwork of Peele uniting his audience's views and his own literary license to generate the complex villain of Barbary. He represents the first black Moor of any dramatic significance. Peele shows the villain Muly Mahamet as cruel and treacherous, and his evil is accompanying directly with the blackness of his skin. The representation of the immorality of the Moor puts into the European superiority.
\end{abstract}

Keywords: Muly Mahamet; the Moor; Negro; the bad other; revenge; blood; murder

\section{Introduction}

George Peele's The Battle of Alcazar (1594) has a special place in Elizabethan image of the Barbary. It embarks upon an extensive description of the Moors who were principally African characters. Peele's Muly Mahamet is the Devil in his likeness. As a family killer, the play opens with a dumb display, which represents the assassination of Muly Mahamet's uncle Abdelmunen and Muly Mahamet's younger brothers. The assassins were led by Muly Mahamet himself. The Moor's stereotype is, likewise, employed openly to expose the supposed heinousness of Moors and to depict Muslims as agents of evil (Tokson, 1982, p.4). The Elizabethan writers also had plenty of opportunity to see Moors and Negroes in England. Indeed, a regular trade between England and Barbary had been exercised during the 1550s and diplomatic relations during the 1570s (Bartels, 1992, p. pp. 517- 9). Samuel C. Chew remarks that 'the imagination and emotions of Englishmen were stirred by The Battle of Alcazar' (Chew, 1937, p.524). Chew also notes that Hakluyt supplied the Elizabethans with abundant information on the customs, manners, laws, religion, government, literature, history, warfare, wealth, cattle, rituals and superstitions of the Oriental peoples (Chew, 1937, p.11). Kabbani remarks that the entire 'East was a place of lascivious sensuality'(Kabbani, 1986, p.5). The performative nature of Moorish identity has interesting implications for the English audience, who can see characters striving to conform to an ideal that may appear horrible or ridiculous to them.

Early Elizabethan Londoners were interested in news and other races of Morocco. It was the reason of presenting Moorish characters in these plays such as The Battle of Alcazar, Titus Andronicus, The Play of Stukeley, The Merchant of Venice, Lust's Dominion, Othello and The Fair Maid of the West. The Elizabethan audience was much informed about the Moors. When it comes to the representation of "others" on the London stage in Elizabethan England, the Moors took a prominent position. John Tolan remarks that on both sides Muslims and Christians had "feelings of rivalry, contempt, and superiority tinged or tempered at times with feelings of doubt, inferiority, curiosity, or admiration" (Tolan, 2002, p.xvii). White Europeans had interpreted the blackness of the Moors as a sign of inborn evil. Moor's ethnic background served as an "amalgam of both religious and colour difference" (Loomba, 2002, p.47). Furthermore, the black or dark skin of Moors and other Muslim people of colour was compared by fair-skinned Europeans with the colour of the devils, burnt black by the flames of hell. In general, to the Elizabethan 
audience a Moor was black, pagan, lustful, treacherous, barbarous and barely human (Abu-Bakr, 1997, p.124). In fact, the depiction of a Moor filled a specific need in the dramatic structure by virtue of the heartless murderer's characteristic of unlimited caution while he remains the African Other in terms of collective interactions. In The Battle of Alcazar, Muly Mahamet's color seems to derive from a particular dramatic necessity. As with a Moor, the playwright does not seem to be exploring the character; he is exploiting the black skin color. The Elizabethan audience is excited by the appearance of the black Muslim Moors (Vaughan, 2005, p.29). Therefore, the history of Moors is interesting as part of the history of the black Other.

The conception of the Otherness exists within the self as well as attached to particular bodies that get labeled and marked as "the Other" (Weems, 2007, p.40). Throughout the fifteenth and sixteenth centuries, English nation was thinking about 'international community of Christendom' (Greenblatt, 2006, p.466). The transgression of power by Muly Abdallah, his son Mohammed el-Mesloukh (Peele's Muly Mahamet) (Note 1) violated the Moorish law of succession. Hence it created unrest, public dispute, and confusion in Barbary. Following the practice of Turkish dynasts, Muly Mohammed el-Mesloukh simply ordered the murder of his uncle Abd el-Moumen and his two brothers to assure succession to his son. Two of the princes, and Abd el-Malek, and Al-Mansoor escaped. In relation to the theatre, Peele's Presenter outlines the dreadful tragic scene as 'Blood will have blood, foul murder scape no scourge' (Act $\mathrm{V}, 8)$. In a dirty civil war, the two rival parties have brought foreign forces to Barbary to support their stands.

\section{The Failed Crusade}

George Peele wrote The Battle of Alcazar in 1589 but it was published in 1594. The play introduced the first black Moor on London stage. Peele's source of the play was John Poleman's The Second Part of the Book of Battailes, Fought in Our Age (1587), which included the Battle of Alcazar between the forces of Sebastian, king of Portugal, and Abdelmelec, the king of Morocco. The dramatic story of the play portrays a bloody fight between Moors and Christians. Peele has confined to the historical event in writing the play. Abdelmelec, who is known as Muly Molocco, is the rightful King of Morocco. But his nephew Muly Mahamet, the Moor, attempts to take his throne. The chorus recounts, through the use of a dumb show (a silent play or portrayal) that Muly Mahamet has slaughtered Abdelmelec's brother Abdelmunen, as well as two young prince brothers. Abdelmunen's wife, Rubin Archis, depicts the dramatic retaliation of the event in saying:

Of death, of blood, of wreak, and deep revenge,

Shall Rubin Archis frame her tragic songs:

In blood, in death, in murder, and misdeed,

This heaven's malice did begin and end. (I,I, 84-7)

King Sebastian has promised military assistance to Muly Mahamet considering that he is performing honourably. On the other side, Sultan Amurath, Emperor of the Turkey, leads army aid to assist Abdelmelec against the Portuguese Sebastian and the Moorish Muly Mahamet. The armies have met in Alcazar valley in Morocco. In the midst of the battle, Abdelmelec died in illness, but his brother Muly Mahamet Seth, concealed the news in order to keep their troops in high morale. The battle works, and Abdelmelec's troops are victorious. Taking the historical context into consideration of Peele's play, the other two kings have died in it, Muly Mahamet and the Portuguese king. However, Abdelmelec's brother, Muly Mahamet Seth (historically known as Almanzor) is declared King of Morocco (MacLean \& Matar, 2011, p.61). In Peele's Alcazar Thomas Stukeley, the disreputable English agent is a protagonist Londoner fighting with the Portuguese king against the Moors (Danson, 2002, p.2). For some Elizabethans, Stukeley is comparable to King Sebastian, and with good reason, for Stukeley too is represented by the playwright as a living legend. He has also died in the battlefield.

Peele shares the sentiment with Sebastian in his campaign against the Turks and the Moors, though he seems against Muly Mahamet and the crusade. He calls this war as 'holy Christian war' in purpose 'To spend their bloods in honour of their Christ' (II,iv,78,82). It is a crusade for the sake of 'Christ, for whom in chief we fight, Hereby t' enlarge the bounds of Christendom' (III,iv, 15-6). This rightful war, that Christians' God will bless. (III,iv,23). The war in Barbary conforms to the concept of the holy war, as it is to implant Christianity in Africa; Sebastian says, that he 'leads the way/To plant the Christian faith in Africa' (III,iv,16). For the Elizabethan audience, the ethical and pious altitudes of the Christian people and cause go hand in hand with the moral and religious degradation of the Turks and the Moors. But Peele is not so keen to consent that Sebastian's war in Morocco actually is a 'holy Christian war' (II,iv,78). Through the tragedy, Peele conserves the admirable nature of Sebastian's announced purposes, and particularly Sebastian's aspiration to the spread of Christianity. Nevertheless, throughout the speeches of the Presenter at interludes during the play, Peele establishes the shameful nature of Sebastian's crusade. Subsequently, the play commemorates the failure of 
English politics in Barbary. Historically, Queen Elizabeth had supported the Portuguese king Don Sebastian, who had assisted Ahmad bin Abdallah to recapture the Moroccan throne after the latter was overthrown by Abdel Malek's forces in 1572 .

The play confirms to the Elizabethan audience that numerous Britons have fought and died in the battle of Alcazar (Matar, 1999, p.49). Nabil Matar argues that the representation of Muslims and Christians is simplistic as the Muslims appear 'bombastic and cruel' while the Christian apprentices are martial heroes 'because they come from England' (Matar, 1999, pp.142-3). The account written by Hohannes Thomas Freigius and reprinted in Hakluyt explains "that divers other [than Stukeley] English gentlemen were in this battle, whereof the most part were slain" (Hakluyt, 1904, Vol. 6, p.294). Captain Stukeley's presence brought a sense of heroism for both the English common soldier and gentleman in the battlefields of Islamic World (Hakluyt, 1904, Vol. 6, p.294). Later in the seventeenth century, when Thomas Fuller reflects on Stukeley, he has again praised him for having "behaved himself most valiantly." Almost everything negative about him has been forgotten (Fuller, 1965, p. 415).

The failed crusade is a message of the internal force in the Elizabethan reign. In history, Queen Elizabeth was quite vigilant to the endangerment of which Peele was warning about agreeing to Abdelmelec's proposal for an alliance. In February 1589, the Queen wrote to Almanzor about her desire to keep the Moroccan ambassador in England as long as possible (Casellas, 2007, p.124). However, in The Battle of Alcazar Peele occludes a significant difference between the Moroccan and English laws of succession: while in England the eldest son inherits the throne, under the Moorish Sa'adians the succession has passed to the eldest member of the immediate family. Peele correctly identifies Abdelmelec as the legitimate and the noble heir to the throne, but he conceals the fact that the villain of his play, Muly Mahamet would have been the legitimate heir according to English traditions of succession. However, this campaign is largely unsuccessful and brought great dishonour to Christendom. It has managed the barbarous black Moors and the white failed Europeans in evil activities and monstrous consequences.

\section{Racial Discourse}

Peele's The Battle of Alcazar (1589) is a racial landscape of Peele's Elizabethan England and Western Europe. Understanding racial blackness in the sixteenth century perspective demonstrates as one of the numerous qualities, physical or otherwise, that isolates and enormously depresses those who grasp it as it is a mark of human nature. Moors and Negroes had opportunity to stay in Elizabethan England. They shared the common connotations of "alien" or "foreigner," the word "can mean...non-black Muslim; black Christian, or black Muslim" (Barthelemy, 1987, p.7). During the early modern period there was a merge of cultural experiences that hadn't, in the past, been experienced which led to a panic of foreigners. In fact, there were so many Negroes in England by 1601 that Queen Elizabeth issued an order for their transportation out of the realm (Obaid, 1974, pp. 150-5). Between 1517 and 1595, several violent demonstrations took place in London to protest for the presence of foreigners working in England. The Parliament tried to appease the people by expelling most Flemish workers and refugees in 1575 (Marienstrass, 1985, p.102).

The Elizabethan racial, linguistic and other cultural aspects among discrete Muslim peoples were acknowledged, and occasionally exploited, but the weight of Medieval Christian tradition intended that they were still, at root, 'Mahometans' to the Christian spectator of early modem times, and with this came an entire series of establishing cultural and/or racial qualities, fundamentally denotative of numerous practices of deviance and threat (Loomba, 2002, pp.45-74). The theatrical Moor of early modern Europe was an actor in blackface. When a "Moor" like Shakespeare's Othello appeared on the London stage in the sixteenth or seventeenth centuries, he was essentially an emblematic figure, not a "naturalistic" portrayal of a particular ethnic type (Cowhig, 1985, p.178). As John Gillies reminds readers of Othello, '. . . the sharper, more elaborately differentiated and more hierarchical character of post-Elizabethan constructions of racial difference are inappropriate to the problems posed by the Elizabethan other' (Gillies, 1994, p.32). Othello is not to be identified with a specific, historically accurate racial category; rather, he is a dramatic symbol of a dark, threatening power at the edge of Christendom. As such, Othello the Moor is associated with a whole set of related terms - "Moor," "Turk," "Ottomite," "Saracen," "Mahometan," "Egyptian," "Judean," "Indian"-all constructed in opposition to Christian faith and virtue. Looking predominantly at the meaning of Othello's description, "the Moor," G. K. Hunter describes how this term was assumed:

'The word "Moor' had no clear racial status" to begin with; "its first meaning in the O.E.D. is "Mahmoden," which itself meant merely "infidel," "non-Christian," "barbarian." "Moors were, as foreign infidels, virtually equivalent to Turks: "the word "Moor" was very vague ethnographically, and very often seems to have meant little more than 'black-skinned outsider,' but it was not vague in its antithetical relationship to the European norm of the civilized white Christian.' (Hunter, 1967, p.147). 
The Elizabethan writers have communicated notorious existing prejudices and stereotypes on those of African descents based solely on their dark complexion. Traditionally, blacks were seen by some as the descendants of Ham (Genesis, ch. 9), one of Noah's three sons. The insistence upon black skin and Negro physic suggests that the Elizabethan playwrights select these racial details from among those Africans who would have provided what Professor Eldred Jones terms the greatest "dramatic contrast" with Europeans (Jones, 1971, p.41). Although blackness and Muslims are stereotyped as evil, Renaissance depictions of the Moor are vague, varied, inconsistent, and contradictory. As Matar, Vitkus and Hunter have established the argument that the term 'Moor' was used interchangeably with such similarly ambiguous terms as 'African,' 'Ethiopian,' 'Negro,' and even 'Indian' to designate a native of Africa or Asia who might be either black or Muslim, neither, or both (Neill, 2000, pp.269-74; Vaughan, 1994, pp.56-8). Cohen remarks that 'the Africans were thus perceived as closer to a life of lust and to Satan' than were the other two marginalised groups (Cohen, 1980, p.8). For instance, the King of Fez, Mullisheg, The Fair Maid of the West is the lustful Moor in Elizabethan Drama. The Moorish character's black skin, evidently, could have derived from any of the blacks seen in England.

The black Moors remain fundamentally unexploited by arguments for racism in Elizabethan Britain. London has held very diverse experience of the inhabitant strangers, identified variously as Moors, Negroes, Indians, and Arabs in the community records, law courts, portfolio and payment lists. Imtiaz Habib detects records for about 100 Londoners from Elizabeth's coronation in 1558 until c. 1605 who were or may have been Moors or Africans (Habib, 2008, pp. 314-39). The Elizabethans frequently dispute, for example, whether or not a person's blackness is purely a physical misfortune or indicative of spiritual impurity and moral depravity. Bayouli notes that 'the Elizabethan playwrights refer to characters as negroes while giving Barbary as their origin' (Bayouli, 2008, p.118). The distinctive variability of Elizabethan awareness of race bears direct impact on the specific way blackness is othered in Elizabethan age. Because so many altered standards are considered estates for racial isolation, implication of blackness on personhood is vastly opposed and varies upon several situations. Therefore, "Blackamoors" are a common feature of conventional plays, pageants and masques, and were specifically accompanying with the forces of darkness, as for instance in Ben Jonson's Masque of Darkness. Jonson's masque turns on the dissimilarity between light and dark; even as the blackness of Peele's Muly Mahamet is underlined in the play for his violence and brutality. Sometimes, the black Moor is categorized alternately and sometimes simultaneously in paradoxical extremes, as barbarous or monstrous \dreadful, civil or savage. However, the different skin color of the Moors in Peele's The Battle of Alcazar (1589), for example, between Muly Mahamet, the prototypical cruel black Moor, and his uncle Abdelmelec, the Orientalized dignified white Moor makes their appearance on stage quite attractive.

The theme of the blackness seems to be reflected in the unanticipated reversal of the color symbolism in Peele. The black skin color, as an element of the characterization of the protagonist, appeals for an explanation getting out of both character and plot. Michael Neill proposes that even 'the putative visibility of the Moor's "aggressive Otherness" was a source of doubt and concern given the term's indeterminacy' (Neill, 2000, p.272). In Peele's play, it puts emphasis on the visual looks of the noblest Muly Mahamet's blackness. His blackness is used to depict Moorish characteristics with bombastic deviousness. He was described as a 'Negro Moor' (II,i,3). The semantic meaning of the adjective 'Negro,' is signified the allusions to Muly Mahamet's character as black like evil or dark as gloom, and so he has no light for peace or morality for humanity. Muly Mahamet's blackness is the colour-prejudiced component of the English audience. His blackness 'remains the appropriate adjective to the ugly and the frightening, to the devil and his children, the wicked and the infidel' (Hunter, 1997, p.35).

Like Peele, Shakespeare in Titus Andronicus (1590) and Othello (1604), for instance, Aaron and Othello, the two Moors embody the most negative versions of the Negro stereotype. Apart from his devotion to his illegitimate child, Aaron is extravagantly evil. He concludes Titus by repenting any good deeds which he may have inadvertently performed and wishing that he could have committed ten thousand more evil deeds (5.3.185-90). While Aaron's adherence to Moorish stereotypes, Shakespeare has made him fascinating as a demonic embodiment of evil but it makes him less interesting as a human being. Peele uses the same Moorish stereotypes to produce the same effect. In The Battle of Alcazar, rivalry becomes psychologically apparent through the barbarous Moor's increasing conformity to his wicked stock character. He thereby identifies himself with Elizabethan archetypes of the villainous Moor of London stage. Yet the process of Muly Mahamet's degeneration into a stereotype is indeed what creates a sense of his inhumanity and complexity. The racial factor itself demonstrates that the character's black skin color should be inherent in the dramatic elements of Muly Mahomet's manners. He represents the black devil of the play. At the end, the Moor is destroyed as the result of the machination of fratricide who is punished within the confines of his dramatic action. The last image of his turns is to turn life black for all.

The Oriental racial discourse brings out unpleasant images of the black Moors. Muly Mahomet reverts to the identity 
of the gloomy devil and the stereotypical cruel 'Moor' or 'Turk' - violence, mercilessness, faithlessness, lawlessness, despair, jealousy, frustrated lust. Othello and Aaron in Shakespeare, Mullisheg in Thomas Heywood or Muly Mahamet and his son and wife in George Peele, are all villainous black Moors, who are also defined by the Eastern world, not "Africa" that lays south to Europe; but his colour symbolized evil, and, like the devil on stage Muly Mahamet is distinguishes from his virtuous half-brother, Abdelmelec, the rightful prince. Peele has rationalized the black Mahamet's dissimilarity by depicting him "Negro" who does not more represent actual Negroes than the evil in Medieval Age.

\section{The Barbarous Moor}

The brutal character of Muly Mahamet is conventionally depicted to represent the Moorish characteristics as opposed to the humanistic ideals by means of the rhetoric of denial, demonization, cursing, animal imagery, and barbarism. Barthelemy notes that the "overwhelming majority" of black characters presented on the stage in England "between 1589 and 1695 endorsed, represented, or were evil" (Barthelemy, 1987:72). For some Elizabethan writers, the Moors do not live up to the humanistic urban, civilized and courtly expectations. In a recent study of the depiction of Moors, Virginia Mason Vaughan's Performing Blackness (2005), examines the idea of the stereotype and the blackface by emphasizing the difference between audiences and talking characters. For Vaughan, there are dramatic signs in performance such as 'appearance, linguistic tropes, speech patterns and plot situations;' she argues for these signs function as a system to shape "the ways black characters were 'read' by white audiences" (Vaughan, 2005, p.3).

The typecasting patterns of black characters are prejudiced. The strength and confidence of the evil black characters are probably more accustomed to the representation on stage of the type of subservient and menial blacks that have appeared in some Elizabethan plays such as Aaron in Shakespeare's Titus Andronicus, and the Moor in Othello, Eleazer in Dekker's Lust's Dominion (1599), etc. Therefore, violent characters such as the Moor Muly Mahamet and his son in George Peele's Battle of Alcazar are strong, self-confident characters, but as blacks, they stood for evil. Muly Mahamet introduces his stereotyped Moorishness as of a 'negro' and 'devil' (II,i,3; III, v, 45) as part of his attempt to act against his native kinsmen. Peele's attempts to demonize and disempower Muly Mahamet for his racial or natural difference that proves the Moor an inferior outsider but to a political status that makes him the authorizing insider and that threatens to keep Muly Mahamet in the margins of power. Peele portrays Muly Mahamet as a barbarous cruel and traitorous rogue, and his evilness is directly associated with the blackness of his skin. Muly Mahamet himself is neatly and absolutely contained within the earth; but by making the fate of his son ambiguous, the play leaves the threat of Moorish badness as ever-present. It exposes the disturbing monarch succession to shape a Moorish culture's actions and reactions, as it drives the attention to the Moorish flux of representation. The play evokes gruesome visions of a Moor who falls quickly into monstrous against his uncles assigning him its most aggressive voice, corrupt ambition as an incontestably wicked villain. In fact, Muly Mahamet's skin colour and negroid looks are primarily the qualities that remarks the devil.

Muly Mahamet's personal characteristics may have seemed at consistency with certain widely-held notions of the proper traits for blacks on London stage. The Elizabethan stereotype of the black Moors is a result of the crystallization of attitudes developed in an attempt to justify pirate slavery (Mattar, 2001, p.189). Although the Moor descends from the noble family Arabian Muly Xarif of Makkah (I,I, 27), he is one of the worst Machiavellian. His stock character charts his immorality and his natural blackness as a manifestation of his wickedness. He is depicted beyond the stereotypical scenes, e.g. villainous bombast, horrific endings, deceptive use of lust, etc.

The tyrannical Moorish king is a typical stage-villain, black in his look and bloody-ill in his deeds. Emily Bartels describes Muly Mahamet, 'the prototypical cruel black Moor' (Bartels, 2008, p.434). His roots lie in most likely an amalgamation of criminals from other Elizabethan plays. She compares 'Muly Mahamet, the prototypical cruel black Moor' with Shakespeare's Aaron, 'the consummate villain' (Bartels, 2008, p.434). Muly Mahamet is a concerning self-hatred devil that colors the earth with its own imagined darkness. Muly Mahamet is a striking example of the traditional Oriental portrayal of the Moors. A variety of qualifying words are used with 'Moor' in reference to Muly Mahamet. The Presenter initiates the play in dubbing Muly Mahamet, the Moor as 'the barbarous Moor', 'The negro,' 'the unhappy traitor-king,' 'the unbelieving Moor,' 'the ambitious tyranny', and 'this accursed Moor' (Act I, 9; 46; 902, 921). In his second comment on the barbarous Moor, the Presenter calls him 'the murderer of his progeny,' 'the cursed king' (Act IV), 'this foul ambitious Moor,' 'the foul murder' (Act V), 'a lusty Moor,' 'manly Moor,' 'brave Moor' (Act IV,41; 949; 972; 998). In fact, the variable use of dubbed phrases such as 'unbelieving Moor' (Act IV,46) and 'accursed Moor' (Act V,54) show the anti-Muslim sentiment familiar among Christian authors at that time. The racial terms such as 'barbarous Moor,' 'Negro Moor' by antagonistic characters, and 'lusty Moor,' 'manly Moor,' 'brave Moor' by friendly 
characters, also show the range of nicknames applied to the Moor. Of these the term 'Negro' is particularly remarkable, for it is not very usually used in the Elizabethan Drama (Note 2).

The theme of the Moor's ambitious tyranny is horrific like Marlowe's Tamburlaine. Peele has seized upon the subject of Alcazar in order to rival Marlowe's Tamburlaine (1598) in its own vein. The pompous speeches of Abdelmelec and the black Moor echo the very diction of Marlowe's play. Peele's Moor recalls the image of Tamburlaine in saying:

Convey Tamburlaine into our Africa here,

To chastise and to menace lawful kings:

Tamburlaine, triumph not, for thou must die,

As Philip did, Caesar, and Caesar's peers. (I,ii, 34-7)

The despicable Moor is the antagonist of The Battle of Alcazar. He is ruthless, irreligious, treacherous and bloody tyrant. His character is largely drawn to be a static, innately evil figure that possesses absolute contempt for mankind. In this way, he represents quite a few of the traditional stereotypes of African blackness. Conversely, his use of nobility, semantic language, and well-expressed speech indicate that the Moor is comprehensively skilled. Thus, this personal appearance opposes the perception of blackness as animalistic and brutal apprehended by Peele's countrymen. In fact, his skin color and low birth are initially the only persona that makes out the Moor as the bad "Other." Muly Mahamet is headed a line of black Moors on the stage included remarkably Aaron, Eleazer and even the hero of Othello. These characters helped to establish the portrait of the villainous Moor in Elizabethan Tragedy.

During the sounds of the battlefield in The Battle of Alcazar, the chorus-like nature of the Presenter introduces the dumb show onto the stage when he remarks on Muly Mahamet as he is 'accompanied as you may now behold, with devils coated in the shapes of men' (II, 22-3) (Note 3). In fact, Muly Mahamet, the wicked Moor orchestrates much of the brutality in his wrongdoing. His villainy in the play is never quite, although it measures up to the rhetoric that establishes his personality in the Presenter's prologue and annotations. Muly Mahamet revels in his physical and spiritual blackness:

...this tyrant king;

Of whom we treat, sprung from th' Arabian Moor,

Black in his look, and bloody in his deeds;

And In his shirt, stained with a cloud of gore,

Presents himself, with naked sword in hand,

Accompanied, as now you may behold,

With devils coated in the shapes of men. (I,15-20)

The barbarous Muly Mahamet reveals his ambition of power in a dramatic venture and, then, project his revenge onto others. Peele tries to entertain his audience with Senecan thoughts of revenge. The revengeful theme increases the tragic flow of Muly Mahomet. For instance, the early Elizabethan Drama of revenge with its tortured hero revenger were popular such as The Spanish Tragedy, Hamlet and Antonio's Revenge, and the Revenge of Honor. It was common in Elizabethan Drama to represent Moors as unjust, tyrannical and lusty pagans associated with Satanism. Muly Mahamet's greedy ambition for power is a typical example for Oriental despotism. This oppressive Moorish king is a distinctive criminal. From the very beginning, he is a treacherous, ready to commit patricide.

The play starts in blood: when the cruel Moor Muly Mahamet and two murderers bring in his uncle Abdelmunen and the young Princes strangled. In the interest of the representation of butchery, Peele has departed from the exact details of the historical account to the Moor Mahamet's guilt. Nonetheless, the Moor's villainy is of a curious sort. For the most part he acts as a devilish source of evil: he delights not in murdering, but in smoothing and escalating the capability of the Moorish characters for murder. A poor example of wickedness is the murder of fratricide and relatives. The Moor establishes a plot whereby Abdelmunen's ghost signifies the need of revenge: Abdel Rayes remarks:

Rubin, these rites to Abdelmunen's ghost

Have pierced by this to Pluto's cave below;

The bells of Pluto ring revenge amain,

The Furies and the fiends conspire with thee;

War bids me draw my weapons for revenge

Of my deep wrongs and my dear brother's death. (II,I, 26-31)

The Elizabethan audience grasps the issue of Moroccan civil bloody revengeful war that lays behind the action about three kings. Peele slightly refers to the bloody passages about the guilt of the villain's father, his grandfather's troubled 
reign which are behind the other horrid events of Muly Mahamet's dramatic action. Peele has focused attention on Muly Mahamet's guilt by means of the first dumb show. Here, Muly Mahamet and his son enter with two of the tyrant's young brothers, who betake them to their rest. The use of the stage bed for a brief scene was a simple and familiar device, an example of how Peele's acquaintance with stage performance helped him to interpret the prose chronicle about Alcazar into chronicle drama (Note 4). Peele's Presenter is completely against the bad Moor. The Presenter is pessimistic of the dark retaliation. He evokes the image of Abdelmunen's grieved ghost for revenge: "Wreak and revenge!"(II,I, 30). This image gives a solid feeling for the retaliation tone and emotion with which the Elizabethan audience sees the killing sight of Abdelmunen and two princes. In fact, Muly Mahamet horrifies the royal family with furious murders, as he feels that his actions are cause for his own right of power. From the very beginning, Muly Mahamet is a Machiavellian, ready to commit patricide. He has disgracefully degenerated his royal family and murdered them.

Muly Mahamet was at once pointed out as the typical Moorish villain. He seems never to be more subtle than the black villain. Because his blackness cannot be removed from his person, the evil that resides within him is immutable as well. D' Amico provides an interesting discussion of the limitations of Muly Mahamet's villainy. He points out that while Muly Mahamet is in many ways a perfect villain, in at least one scene he displays valour and nobility of spirit ( $\mathrm{D}^{\prime}$ Amico, 1991, pp.45-46). Loomba argues that conventionally, "blackness was a symbol for a variety of differences...[it] represents danger, becoming a way of signifying what lies outside familiar or approved social, political, religious, and sexual structures" (Loomba, 2002, p.36). The Moor is humanly unapologetic. He is barbarous even in making 'his food' which 'is the flesh of savage beasts' (II,ii 15). When the vicious Moor asked his wife to eat lioness's flesh, Peele probably re-echoes the description of eating beast-flesh of his personal experiences and stories in his travels in the East. Naji Oueijan remarks that Elizabethan travel books have also helped popularize the false image of Islam and the Orient (Oueijan, 1996, pp.11-12). Normal Daniel finds out that this 'tradition inherited from the Medieval West' (Daniel, 1966, p.282). In the play, Muly Mahamet enters the stage the Moor with flesh upon his sword to feed his wife, Calipolis. He shouts out:

Hold thee, Calipolis, feed, and faint no more;

This flesh I forced from a lioness,

Meat of a princess, for a princess meet:

Learn by her noble stomach to esteem

Penury plenty in extremest dearth $\backslash . .$.

Feed, then, and faint not, fair Calipolis;

For rather than fierce famine shall prevail

To gnaw thy entrails with her thorny teeth,

The conquering lioness shall attend on thee,

And lay huge heaps of slaughtered carcasses,

As bulwarks in her way, to keep her back. \...।

Feed, then, and faint not, fair Calipolis. (II, iii, 89-120)

In contrast, when the Moor Aaron has intended to eat the human flesh of the Moorish child, Shakespeare represents Aaron as a horrific villain (Shakespeare's Titus, 1995, p.50). Muly Mahamet's eloquent speech as king of Barbary does not decline his status as Machiavellian Negro. Peele's interpretation of Elizabethan perceptions of blackness depicts them as curving frankly from the European tradition of typecasting the darker-toned Moor of the sixteenth century period. Muly Mahamet insists that his Queen Calipolis should eat and get ready for the worse:

Into the shades, then, fair Calipolis,

And make thy son and Negroes here good cheer:

Feed and be fat, that we may meet the foe

With strength and terror, to revenge our wrong. (II, iii, 77-81)

The Elizabethan prevailing cultural view of blackness is traditional. The Moor's complexion is permanent and marks all who comes from Africa. Admittedly, The Battle of the Alcazar's depiction of the Moors inspires understandings that reflect the conflicting visions inscribed in Elizabethan discourse. Peele's Muly Mahamet might have influenced Shakespeare to make the important deviations from his source in his handling of the roles of Othello and Aaron. Therefore, the Moors are identified to be of a different race than the majority. In addition to Africans, racially 
"Othered" ethics in Elizabethan England involve laborers, Turks, Arabs, and Muslims. In accordance with a literary critic, Ania Loomba states that race is accordingly exploited as a device to exercise power over a range of minority groups, and it continues 'a highly malleable category which historically has been deployed to reinforce existing social hierarchies and create new ones' (Loomba, 2002, p.3). Loomba describes Elizabethan discrimination of race as a 'distinct social group whose physical difference corresponds to inner qualities' (Loomba, 2002, p.27). Elizabethan stereotypes progressively arise from those warring attitudes, as 'the stages of the early modern period were rife with images of black people as lewd, unprincipled, and evil, ugly and repulsive' (Loomba, 2002, p.36).

The most complex and harshly treated of Peele's Moorish distinct personality is woven entirely from the black social conception in Elizabethan London. Peele's austere understanding of barbarous tyranny that tackles the plot is entirely Oriental in root. Muly Mahamet views these traits as a source of monarch pride that tangibly connects him to his religious Arabian ancestors, stating that it is his legitimate right to inherit the throne of Barbary. Simultaneously, Muly Mahamet is the conniving, and soulless African. He claims the monarch of Morocco but he is offensive and a social threat to Barbary. In killing others, he is proud of the bloody scene of the battle. He has encouraged these gory scenes to happen:

This mass of flesh, this cursed crazed corpse,

Destroy, dissolve, disturb, and dissipate,

What water, earth, and air congealed! (V,i, 58-61)

Through Muly Mahamet's appearance on stage, the barbarous Oriental character is already physically prominent and strange. Muly Mahamet provides an absolute opposition to the Christian ethics of charity and forgiveness that Elizabethans appear to consider they absolutely possess. Indeed, the Moors are considered to be of less moral quality than Elizabethans. The Moor's subsequent character has allowed the Elizabethan Peele to portray emerging late sixteenth century cultural diversity as a principal of European social structure. The Battle of Alcazar is a historical play also called a tragedy of blood, gives a revealing instance of the Elizabethan playwright's use of the Oriental theme. An Oriental blood tragedy is believed to succeed because it had the characteristics of strangeness and plausibility.

\section{Conclusion}

The play is written due to the interest of the Elizabethan audience in Oriental matters. The Oriental element in Peele is varied, elusive and perceptive. The play embodies the Oriental Moors on London stage in the historical context and the racial discourse that The Battle of Alcazar is fundamentally concerned with. Muly Mahamet is the stable and unambiguous sign of imperial Otherness in the play. Though the judgment of the Moor's character by others in the play is simply seen to run from the traditions of Peele's Elizabethan culture, the noble Muly Hamet's character is first slightly interrupted in the play text before the villain in due course conveys his innermost beliefs about himself and the people in which he lives upon his detention and imminent execution at the end. On the same way, the other noble Moor Abdelmelec works as a witness to the Moorish truthful history of unspeakable wrongs of the barbarous Moor. Muly Mahamet's ethnic background that relates to negro race is involved for the purpose of lending authenticity to the character's black skin color and for the purpose of labeling an indigenous black of any race.

Muly Mahamet's blackness is used by Peele primarily to support the fact of the Moor's black skin color suggests an evil dramaturgical drive in light of his brutal Moorish race. In terms of Peele's racial portrait, the racial conception of Muly Mahamet is a symbolic Machiavellian domain in the Oriental tradition of Elizabethan bloody tragedy. Peele's first play shows bloody scenes which strongly mark all Elizabethan revengeful drama. The vicious cruelty of the Moors is beaten by the bloody passion of Muly Mahamet. Charles Gildon has found that Elizabethan perception considered such "a Moor there could be no just fear of treachery in favour of the Mahometans" (Gildon, 1974, p.72). Therefore, the treachery of black ethnicity is propagated in Elizabethan Drama by Peele's Muly Mahamet and then Shakespeare's Othello and Aaron, and Dekker's Eleazer. It is a type of social shock which in turn has complicated ties with sexual and racial anxieties.

The distinguishing features of Elizabethan literary Moorishness represent a significant advance in both the scope and range of attention and use. It is non-religious and comprises supplementary information. Far from being merely colourful or a pretext for moralizing or satirizing, it often reflects an interest in the Orient and its people as a subject for creativity and imagination. As Louis Wann points out that 'the production of the Oriental plays was due to the interest of the Elizabethan audience in Oriental matters' (Wann, 1915, p.163). Peele has served the Moors' purpose. In presenting Muly Mahamet as simultaneously frightening and unattractive, Peele reproduces the contradiction of 
English outlooks toward the Moors as defined by some recent scholars. Bartels remarks that 'while the demonization of Oriental rulers provided a highly charged impetus for England's own attempts to dominate the East, their valorization provided a model for admiration and imitation, shaming or schooling the English into supremacy, or providing an excuse for defeat' (Bartels, 1992, p.5).

To sum up, Peele could be demonstrating, in the general nature of Muly Mahamet's background and the ambiguity of the cultural details in his portrayal, that the bad Other is always a stock devil. Although he may be the dreadful Other in his relationship to the majority of Moors, he is located securely within a tradition, a culture, and a history. However, Muly Mahamet's role does not seem to be designed for the purpose of exploring the character of a Moor but rather of exploiting the characteristics of a murderer. The dramatic structure called for a character who takes no chances. Peele finds such a feature in the character of a black murderer, and black pirates at that time are many Moorish and Turkish pirates threatened naval security (Matar, 1999, p.53). Consequently, Peele waves into his plot the Moorish slaughterers in advance for any implied anti-Islamic by placing in Moor's mouth a moving plea for understanding (Alcazar. 3.1.53-73). Peele's The Battle of the Alcazar is a document illustrating Elizabethan racism. Peele and his contemporary audiences recognize the pernicious notions about blacks so Muly Mahamet's murder bears a singular violence or aggression that, in performance, almost compulsively assimilates itself to his Moorish features. Moorish cruelty and violence are threatened and then banished, but it isn't the only play performed in the Elizabethan theatre that has brought Moorish villains to London stage to demonstrate Moorish culture in the form of Moorish characters. For London theatregoers, the Moors are not fictional creatures, and the Moorish plays are not simply fantasies about fictitious fiends lurking at the edges of the sophisticated world. The Elizabethan playwriting expresses an apprehensive curiosity in Moorish authority.

\section{References}

Abu-Bakr, Mohamed Hassan. (1997). Representations of Islam and Muslims in Early Modern English Drama from Marlowe to Massinger. Unpublished Thesis: University of Glasgow.

Bartels, Emily C. (1992). The Double Vision of the East: Imperialist Self-Construction in Marlowe's Tamburlaine, Part One. Renaissance Drama 23. http://dx.doi.org/10.9783/9780812200294

Bartels, Emily C. (2008). Speaking of the Moor: From Alcazar to Othello. Philadelphia: University of Pennsylvania Press.

Barthelemy, Anthony. (1987). Black Face, Maligned Race: The Representation of Blacks in English Drama from Shakespeare to Southene. Baton Rouge, Louisiana State UP.

Bayouli, Tahar. (2008). "Elizabethan Orientalism and its Contexts: The Representation of the Orient in Early Modern English Drama" IJEMS, I(1), 109- 128.

Casellas, Jesús López-Peláez. (2007). 'What Good Newes from Barbary?' Nascent Capitalism, North-Africans and the Construction of English Identity in Thomas Heywood's Drama. Atlantis, 29(1), 30.

Chew, S.C. (1937). The Crescent and The Rose: Islam and England During The Renaissance. New York, Oxford University Press.

Cohen, William B. (1980). The French Encounter with Africans: White Response To Blacks. 1530-1880. Bloomington \& London: Indiana University Press.

Cowhig, Ruth. (1985). "Blacks in English Renaissance Drama and the Role of Shakespeare's Othello. In The Black Presence in English Literature(ed.), D. Dabydeen. Manchester, UP.

D'Amico, Jack (1991). The Moor in English Renaissance Drama. Tampa, University of South Florida.

Daniel, Norman. (1966). Islam and the West. Edinburgh, Edinburgh University Press.

Danson, Lawrence. (2002). England, Islam, and the Mediterranean Drama: Othello and Others. Journal for Early Modern Cultural Studies, 2(2), 1-25.

Fuller, Thomas. (1965). The History of the Worthies of England. New York: AMS Press.

Gildon, Charles. (1974). The life and strange surprizing adventures of Mr. D---- de F--, of London, hosier, who has liv'd above fifty years by himself, in the Kingdoms of North and South Britain. London: printed for J. Roberts.

Gillies, John. (1994). Shakespeare and the Geography of Difference. Cambridge, UP.

Greenblatt, Stephen, et al.(eds.) (2006). The Norton Anthology of English Literature(8th edition.). New York: Norton 
\& Co.

Habib, Imtiaz. (2008). Black Lives in the English Archives, 1500-1677: Imprints of the Invisible. Burlington VT, Ashgate.

Hakluyt, Richard. (1904). The Principal Navigations Voyages Traffiques \& Discoveries of the English Nation: Made by Sea or Over-land to the Remote and Farthest Distant Quarters of the Earth at any time within the compasse of these 1600 Yeeres, 12 vols. (1589); Glasgow: James MacLehose and Sons, Vol. 6.

Hunter, G. K. (1967). Othello and Colour Prejudice. Proceedings of the British Academy, 53(1967), 147.

Hunter, G.K. (1978). Dramatic Identities and Cultural Tradition: Studies in Shakespeare and His Contemporaries. New York: Barnes \& Noble.

Jones, Eldred D. (1971). The Elizabethan Image of Africa (Charlottes-ville: Univ. Press of Virginia.

Kabbani, Rana. (1986). Europe's Myths of Orient: Devise and Rule. London: Macmillan. http://dx.doi.org/10.1007/978-1-349-07320-7

Loomba, Ania. (2002). Shakespeare, Race, and Colonialism. New York: Oxford University Press.

MacLean, Gerald and Matar, Nabil. (2011). Britain and the Islamic World 1558-1713. Oxford University Press. http://dx.doi.org/10.1093/acprof:oso/9780199203185.001.0001

Marienstrass, Richard. (1985) New Perspectives on the Shakespearian World. Cambridge: Cambridge UP/Paris: Edition de la maison des sciences de l'homme.

Matar, Nabil. (1999). Turks, Moors, and Englishmen in the Age of Discovery. New York, Columbia University Press.

Neill, M. (2001). Putting History to the Question: Power, Politics, and Society in English Renaissance Drama. New York: Columbia University Press.

Obaid, Thoraya Ahmed. (1974). The Moor Figure in English Renaissance Drama. unpublished PhD Dissertation, Wayne State University.

Oueijan, Naji B. (1996). The Progress of An Image: The East in English Literature. New York, Peter Lang.

Shakespeare, William. (1995). Titus Andronicus, ed. Jonathan Bate, London: Clays. http://dx.doi.org/10.5040/9781408160121.00000031

Tokson, Elliot H. (1982). The Popular Image of the Black Man in English Drama, 1550-1688. Boston: G. K. Hall and Co.

Tolan, John V. (2002). Saracens: Islam in the Medieval European Imagination. New York, Columbia University Press.

Vaughan, V. M. (1994). Othello: A Contextual History. Cambridge, MA: Cambridge University Press. Vickers, B. (1974-81). Shakespeare: The Critical Heritage. London: Routledge and Kegan Paul.

Vaughan, Virginia M. (2005). Performing Blackness on English Stages, 1500-1800. Cambridge, UP.

Wann, Louis. (1915). The Oriental in Elizabethan Drama. Modern Philology, XII, $423-447$. http://dx.doi.org/10.1086/386971

Weems, Lisa. (2007). To be Mindful of Otherness' Toward a Post Psychoanalytic Problematic of Ethics and Education. Ohio Valiey Philosophy of Education Society, 38(2007), 37-50.

\section{Notes}

Note 1. Alternately, the play has been convincingly identified with the "Mahomet" of Henslowe's records. See Martin Wiggins, "A Choice of Impossible Things: Dating the Revival of The Battle of Alcazar" Shakepeare and ses contemporains: Actes de colloque 2002 del le Societie Francais Shakespeare ed. Patricia Dorval (Montpellier 2002), p.16.

Note 2. The Edition used for references: The Battle of Alcazar, ed. W. W. Greg, (1917). (The letters $i$, $u$ and who have been modernized when necessary. The printed text of George Peele's The Battle of Alcazar survives in the 1594 quarto.) For a succinct summary of the evidence for Peele's authorship of the play first advanced by Edward Malone, see Charles Edelman, The Stukeley Plays (Manchester: Manchester University Press 2005) 16-18. 
Note 3. Elizabeth Ketterer, (2009) “Govern'd by Stops, Aw'd by Dividing Notes" The Function of Music in the Extant Repertory of the Admiral's Men 1594-1621, The Shakespeare Institute Department of English (The University of Birmingham April 2009).

Note 4. For notes on the established use of the stage bed in scenes like this one, see Lily B. Campbell, (1923) Scenes and Machines on the English Stage during the Renaissance, Cambridge, pp. 138-139. 